\title{
PENERAPAN MODEL PEMBELAJARAN HANDS-ON PADA MATERI STATISTIKA UNTUK MENINGKATKAN HASIL BELAJAR SISWA KELAS IX- E SMPN 1 CIREBON TAHUN PELAJARAN 2015/2016
}

\author{
Yeyet Trisilahayati
}

\author{
SMPN 1 CIREBON \\ Jl. Siliwangi No.125, Cirebon, Jawa Barat \\ trisilahayatiyeyet@gmail.com
}

\begin{abstract}
Pada pembelajaran matematika, guru dituntut untuk lebih kreatif dalam menerapkan matematika ke dalam masalah-masalah kontekstual pada kehidupan sehari-hari, agar pembelajaran lebih bermakna dan siswa merasa lebih termotivasi. Selain itu, dengan adanya tuntutan kurikulum 2013, pembelajaran lebih terpusat pada siswa, sehingga siswa dituntut untuk lebih aktif dalam kegiatan belajar mengajar, namun berdasarkan observasi awal juga, bahwa fakta yang terdapat di SMPN 1 Cirebon menunjukkan belum semua siswa aktif di kelas, dan 60\% hasil belajar siswa masih dibawah KKM. Hal ini terungkap, bahwa proses pembelajaran matematika membutuhkan metode pembelajaran yang kreatif dan inovatif, salah satunya adalah metode pembelajaran hands-on.

Penelitian dilaksanakan berdasarkan rumusan masalah yaitu: apakah penerapan pembelajaran berbasis hands-on dapat meningkatkan hasil belajar siswa pada materi statistikadi Kelas IX-E SMPN 1 tahun pelajaran 2015/2016

Penelitian ini dilaksanakan pada Siswa kelas IX-E SMPN 1 Cirebon pada pokok bahasan statistika. Penelitian ini melalui penerapan Hands-on merupakan penelitian tindakan kelas. Penelitian dilaksanakan selama 2 pertemuan dengan menggunakan beberapa instrumen penelitian, yaitu instrumen observasi digunakan untuk mengetahui aktivitas siswa dan instrumen tes untuk mengetahui prestasi belajar siswa.

Penerapan metode hands-on dapat meningkatkan hasil belajar siswa kelas IX-E SMPN 1 Cirebon tahun pelajaran 2015/2016 pada materi statsitika. Hal ini ditujukkan pada siklus 1 diperoleh nilai rata-rata kelas sebesar 77 dengan persentase ketuntasan belajar klasikal sebesar $51 \%$ masuk kategori belum berhasil. Pada siklus 2 terjadi peningkatan, untuk nilai rata-rata kelas diperoleh sebesar 79 dengan persentase ketuntasan belajar kalasikal sebesar 92\% dalam kategori berhasil. Penerapan metode hands-on dapat meningkatkan aktivitas belajar Siswa kelas IX-E SMPN 1 Cirebon tahun pelajaran 2015/2016. Hal ini dapat dilihat dari hasil pengamatan terhadap siswa pada siklus 1 diperoleh skor sebesar 65,7 dalam kategori sedang, kemudian meningkat di siklus 2 sebesar 81 dalam kategori baik.
\end{abstract}

Keyword : Hands-on, hasil belajar

\section{PENDAHULUAN}

Matematika merupakan disiplin ilmu yang bersifat khas, salah satu kekhasannya adalah memuat konsep-konsep yang bersifat abstrak, namun sesungguhnya matematika sangat erat hubungannya dengan kehidupan sehari-hari. Hal ini sesuai dengan fakta yang terdapat di SMPN 1 Cirebon. Berdasarkan hasil observasi awal melalui wawancara dengan salah satu guru matematika di SMPN 1 Cirebon serta angket siswa,bahwa pada dasarnya siswa merasa senang terhadap pelajaran matematika, karena sesungguhnya matematika 
sangat berguna dalam kehidupan sehari-hari. Selain itu, siswa menganggap bahwa pembelajaran matematika kurang bersifat aplikatif, tetapi hanya sebatas teori. Salah satu penyebabnya adalah metode pembelajaran yang biasa digunakan kurang bervariasi. Oleh karena itu, terkadang siswa merasa jenuh dan bosan, terlebih lagi jika dihadapkan dengan materi-materi yang lebih sulit dan membingungkan.

Pemahaman konseptual dalam matematika mencakup kemampuan untuk merepresentasikan dan menerjemahkan masalah-masalah matematika dalam perhitungan maupun logika. Penyampaian konsepkonsep matematika yang pada umumnya bersifat abstrak sangat sulit divisualisasikan dalam bentuk verbal, sehingga menuntut kemampuan guru untuk mengorganisasi isi pelajaran yang dapat menstimulasi proses sebagai persiapan untuk membangun pengetahuan siswa. Sebagai contoh, konsep matematika yang butuh pemahaman yang lebih dalam adalah statistika.

Pada

pembelajaran

matematika, guru dituntut untuk lebih kreatif dalam menerapkan matematika ke dalam masalahmasalah kontekstual pada kehidupan sehari-hari, agar pembelajaran lebih bermakna dan siswa merasa lebih termotivasi. Selain itu, dengan adanya tuntutan kurikulum 2013, pembelajaran lebih terpusat pada siswa, sehingga siswa dituntut untuk lebih aktif dalam kegiatan belajar mengajar, namun berdasarkan observasi awal juga, bahwa fakta yang terdapat di SMPN 1 Cirebon menunjukkan belum semua siswa aktif di kelas, dan $60 \%$ hasil belajar siswa masih dibawah KKM. Hal ini terungkap, bahwa proses pembelajaran matematika membutuhkan metode pembelajaran yang kreatif dan inovatif, salah satunya adalah metode pembelajaran hands-on.

Pembelajaran berbasis hands-on adalah suatu metode untukk mempelajari pengetahuan dengan menggunakan peraga/material objek yang disituasikan untuk dapat disentuh dan dimainkan sehingga menimbulkan fenomena ilmu pengetahuan yang dapat diobservasi dan diamati (Bop Script, 2004).

Kegiatan hands-on menunjang sekali pembelajaran kontekstual dengan karakteristik sebagaimana disebutkan oleh Hatta (2003) (dalam Amin M, 2007) yaitu: kerjasama, saling menunjang, gembira, belajar dengan bergairah, pembelajaran terintegrasi, menggunakan berbagai sumber, siswa aktif, menyenangkan, tidak membosankan, sharing dengan teman, siswa kritis dan guru kreatif.

$\begin{array}{ccc}\text { Menurut } & \text { Onitsuka } & \text { (2011) } \\ \text { aktivitas } & \text { hands-on } & \text { dapat }\end{array}$
meningkatkan daya ingatan murid tentang apa yang dipelajari dengan lebih cepat serta dapat mengingatinya dalam waktu yang lebih lama, aktivitas hands-on juga memudahkan murid untuk memahami apa yang dipelajari dengan lebih mudah, setelah melalui proses pembelajaran berbasis hands-on, murid akan dapat memindahkan pengalaman yang dipelajari dalam situasi kehidupan yang bersesuaian.

Berdasarkan uraian tersebut dapat disimpulkan, bahwa penerapan pembelajaran hands-on sangat cocok untuk materi statistika, karena materi tersebut membutuhkan peraga/material objek yang disituasikan untuk dapat disentuh dan dimainkan sehingga menimbulkan fenomena ilmu pengetahuan yang dapat diobservasi dan diamati, dengan demikian siswa akan merasa senang, aktif dan fokus dalam proses pembelajaran, sehingga hasil belajar siswa dapat meningkat baik kognitifnya maupun afektifnya.

\section{METODE PENELITIAN}

Metode yang digunakan dalam penelitian ini adalah penelitian tindakan kelas menurut Suharsimi Arikunto, at.al. (2006:3) mengemukakan "Penelitian tindakan kelas merupakan suatu pencermatan 
terhadap kegiatan belajar berupa sebuah tindakan, yang sengaja dimunculkan dan terjadi dalam sebuah kelas secara bersama". Jadi PTK bisa dikatakan suatu tindakan yang disengaja untuk mendapatkan kegiatan belajar mengajar dengan hasil yang maksimal yang berfokus pada kegiatan pembelajaran. Penelitian tindakan kelas dilaksanakan di kelas IX-E SMPN 1 Cirebon yang berjumlah 40 siswa.

Penelitian tindakan kelas ini terdiri dari 3 siklus. Dalam penelitian tindakan kelas ini menggunakan model spiral yang terdiri dari 4 tahap meliputi perencanaan, pelaksanaan tindakan, observasi, refleksi dan perbaikan rencana dalam setiap siklus. Data yang diperoleh melalui penelitian ini dikumpulkan dan dianalisis secara deskriptif. Data aktivitas siswa selama proses pembelajaran, data hasil tes akhir siswa dikumpulkan dan dianalisis baru kemudian dijabarkan dengan menguraikannya dalam bentuk statistik deskriptif.

Instrumen penelitian yang digunakan dalam penelitian tindakan kelas ini sebagai berikut: 1) Lembar tes, dalam penelitian ini post test digunakan untuk mengetahui sejauh mana ketuntasan belajar yang dapat dicapai dengan menggunakan penerapan model pembelajaran Hands-on. Berdasarkan GBPP SMU tahun 2006, bahwa siswa akan tuntas belajar bila ia telah memperoleh skor $75 \%$ atau nilai 75 . Tuntas dalam hal ini adalah siswa telah berhasil belajar pada materi barisan bilangan. 2). Lembar Observasi, digunakan berupa lembar pengamatan melalui penerapan model pembelajaran Hands-on dan lembar aktivitas siswa. hal ini dilakukan untuk menilai keterampilan-keterampilan siswa, apakah kegiatan pembelajaran tersebut berpusat pada siswa.

\section{HASIL DAN PEMBAHASAN}

Pada pembelajaran matematika, guru dituntut untuk lebih kreatif dalam menerapkan matematika ke dalam masalah-masalah kontekstual pada kehidupan sehari-hari, agar pembelajaran lebih bermakna dan siswa merasa lebih termotivasi. Selain itu, dengan adanya tuntutan kurikulum 2013, pembelajaran lebih terpusat pada siswa, sehingga siswa dituntut untuk lebih aktif dalam kegiatan belajar mengajar, namun berdasarkan observasi awal juga, bahwa fakta yang terdapat di SMPN 1 Cirebon menunjukkan belum semua siswa aktif di kelas, dan $60 \%$ hasil belajar siswa masih dibawah KKM. Hal ini terungkap, bahwa proses pembelajaran matematika membutuhkan metode pembelajaran yang kreatif dan inovatif, salah satunya adalah metode pembelajaran hands-on.

Berdasarkan hasil penelitian yang telah dilakukan oleh peneliti terhadap siswa kelas IX-E SMPN 1 Cirebon tahun pelajaran 2015/2016. Penelitian ini dilakukan sebanyak 2 siklus, setiap siklus terdiri dari 2 kali pertemuan dengan waktu 6 jam pelajaran. Penelitian ini berawal dari permasalahan pembelajaran matematika pada materi statistika siswa kelas IX-E SMPN 1 Cirebon. Untuk mengatasi permasalahan tersebut peneliti menerapkan metode hands-on untuk meningkatkan hasil belajar siswa kelas IX-E SMPN 1 Cirebon tahun pelajaran 2015/2016.

\section{PELAKSANAAN TINDAKAN SIKLUS I}

\section{a. Persiapan (planning)}

Siklus I ini diawali dengan persiapan guru dalam menentukan metode pembelajaran yang sesuai dengan materi yang disiapkan, dengan waktu masing-masing 2 jam pelajaran (2 x 40 menit). Guru mengidentifikasi kebutuhan siswa akan pengetahuan yang mereka butuhkan dalam pokok bahasan statistika, menyeleksi pendahuluan terhadap konsep yang dipelajari, yaitu dengan menyusun rencana pelaksanaan pembelajaran (RPP) materi statistika, menyeleksi bahan dan masalah yang akan dipelajari, yaitu dengan mempersiapkan alat dan bahan 
matematika sebagai kebutuhan metode hands-on, serta membuat bahan ajar yaitu materi statistika .

\section{b. Pelaksanaan (acting)}

Kegiatan pendahuluan, guru menyampaikan tujuan pembelajaran, mengingatkan kembali materi pertemuan sebelumnya dan menginformasikan model pembelajaran Hands-on yang akan digunakan.

Dalam kegiatan inti, guru meminta siswa berkelompok. Jumlah anggota kelompok berbeda. Hal ini dimaksudkan agar mendapat data yang bervariasi. Kemudian siswa mengerjakan LKS yang sudah dipersiapkan guru. Selama siswa mengerjakan LKS, guru memberikan bimbingan, bantuan dan mengarahkan siswa yang mendapatkan kesulitan. Kemudian setiap kelompok mempersentasikan di depan kelas, mentukan nilai mean dengan cara mengumpulkan benda (alat tulis) yang diterima, dijumlahkan kemudian dibagi banyak anggota kelompok, siswa yang mendapat benda (alat tulis) lebih dari teman-temannya langsung memberikan pada temannya yang mendapat sedikit dan mengaturnya, sehingga setiap anggota mendapat banyak alat tulis yang sama (nilai/ratarata mean). Kelompok lain dipersilahkan menanggapi, bertanya dan mencatat hasilnya. Guru memadu dan membimbing siswa dalam menentukan jawaban yang benar.

Pada kegiatan penutup, guru membimbing siswa untuk membuat rangkuman materi pelajaran. Kemudian memberikan tugas mengerjakan latihan, siswa diminta menjawab angket yang telah disediakan, untuk mengetahui apakah pembelajaran hari ini menyenangkan atau tidak bagi siswa.
Sedangkan untuk prosentase ketuntasan nilai siswa dalam proses pembelajaran statistika siswa kelas IX-E pada siklus I dapat dilihat pada

\section{Ketuntasan Hasil Belajar \\ - Tuntas $\square$ Tidak Tuntas}
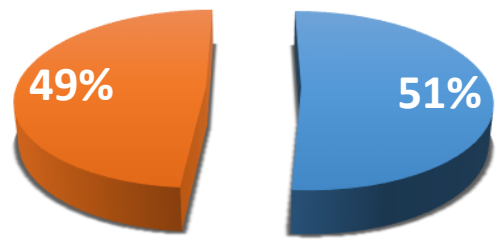

gambar 1.

Gambar 4.1. Ketuntasan Hasil Belajar Siswa

Secara garis besar siswa kelas IX-E SMPN 1 Cirebon tahun pelajaran 2015/2016 sudah menunjukkan peningkatan. Dengan menggunakan metode hands-on siswa sudah mulai memahami materi statistika, serta aktivitas hands-on juga dapat meningkatkan daya ingatan murid tentang apa yang dipelajari dengan lebih cepat serta dapat mengingatinya dalam waktu yang lebih lama.

\section{c. Pengamatan (observing)}

1) Hasil observasi aktivitas siswa Adapun data hasil observasi yang diperoleh metode hands-on dapat meningkatkan pengetahuan dan pemahaman siswa mengenai materi statistika, penyelesaian soal dengan menggunakan metode hands-on mampu meningkatkan minat untuk melibatkan diri dalam aktivitas pengajaran dan pembelajaran.

Observer melakukan pengamatan gambaran aktivitas siswa dalam proses belajar mengajar selama KBM. Selanjutnya data yang diperoleh sebagai gambaran aktivitas siswa dalam proses belajar mengajar selama 80 menit, yang disajikan dalam tabel : 
Tabel 1

Persentase rata-rata aktivitas siswa dengan menggunakan metode hands-on pada siklus I

\begin{tabular}{|c|c|c|}
\hline $\begin{array}{l}\mathbf{N} \\
\mathbf{0}\end{array}$ & $\begin{array}{c}\text { Kategori } \\
\text { Pengamat } \\
\text { an }\end{array}$ & $\begin{array}{c}\text { Perse } \\
\text { ntase } \\
\text { aktivi } \\
\text { tas } \\
\text { siswa }\end{array}$ \\
\hline 1 & $\begin{array}{l}\text { Siswa } \\
\text { mengikuti } \\
\text { pembelajara } \\
\text { n dengan } \\
\text { baik. }\end{array}$ & 75 \\
\hline 2 & $\begin{array}{l}\text { Siswa } \\
\text { bersikap } \\
\text { disiplin } \\
\text { dalam } \\
\text { KBM. }\end{array}$ & 60 \\
\hline 3 & $\begin{array}{l}\text { Siswa } \\
\text { berusaha } \\
\text { memahami } \\
\text { materi. }\end{array}$ & 76 \\
\hline 4 & $\begin{array}{l}\text { Siswa } \\
\text { mampu } \\
\text { bekerja } \\
\text { sama } \\
\text { dengan } \\
\text { siswa } \\
\text { lainnya } \\
\text { melalui } \\
\text { pembelajara } \\
\text { n dengan } \\
\text { menerapka } \\
\text { n metode } \\
\text { Hands On }\end{array}$ & 60 \\
\hline 5 & $\begin{array}{l}\text { Siswa } \\
\text { mempresen } \\
\text { tasikan } \\
\text { penyelesaia } \\
\text { n soal } \\
\text { dengan } \\
\text { metode } \\
\text { Hands-on }\end{array}$ & 75 \\
\hline 6 & $\begin{array}{l}\text { Siswa } \\
\text { mampu } \\
\text { memahami } \\
\text { pokok } \\
\text { bahasan } \\
\text { statistika } \\
\text { yang } \\
\text { sedang } \\
\end{array}$ & 50 \\
\hline
\end{tabular}

\begin{tabular}{|c|l|c|}
\hline & $\begin{array}{l}\text { diajarkan } \\
\text { oleh guru. }\end{array}$ & \\
\hline 7 & $\begin{array}{l}\text { Siswa } \\
\text { mengerjaka } \\
\text { n soal } \\
\text { latihan dan } \\
\text { melakukan } \\
\text { tugasnya } \\
\text { dengan baik }\end{array}$ & \\
\hline 8 & $\begin{array}{l}\text { Siswa } \\
\text { mengkomun } \\
\text { ikasikan } \\
\text { hasil } \\
\text { presentasi } \\
\text { kelompok } \\
\text { lain }\end{array}$ & \\
\hline 9 & $\begin{array}{l}\text { Siswa } \\
\text { mengemuka } \\
\text { kan } \\
\text { pendapat } \\
\text { dan } \\
\text { menarik } \\
\text { kesimpulan } \\
\text { dari materi } \\
\text { yang } \\
\text { disampaika } \\
\text { n. }\end{array}$ & \\
\hline 1 & \\
\hline $\begin{array}{l}\text { Siswa } \\
\text { mampu } \\
\text { menggunak } \\
\text { an waktu } \\
\text { dengan } \\
\text { baik. }\end{array}$ & \\
\hline Rata-rata & \\
\hline
\end{tabular}

Berdasarkan Tabel $\quad 1$ menunjukkan bahwa aktivitas siswa yang diamati oleh observer memperoleh nilai sebesar 65,7dengan kriteria sedang. Hal ini dapat disimpulkan bahwa aktivitas siswa dalam statistika dengan menggunakan metode hands-on pada siklus 1 belum berhasil dan perlu ada perbaikan pada siklus berikutnya.

2) Peningkatan hasil belajar siswa Selanjutnya mengenai data tes peningkatan hasil belajar siswa dalam pokok bahasan statistika, disajikan dalam ringkasan tabel berikut: 
Tabel 2

Nilai tes hasil belajar siswa siklus

\begin{tabular}{|c|c|c|c|}
\hline \multicolumn{1}{|c}{ I } \\
$\begin{array}{c}\text { ahl } \\
\text { siswa }\end{array}$ & $\begin{array}{c}\text { Tot } \\
\text { al } \\
\text { nila } \\
\text { i }\end{array}$ & $\begin{array}{c}\text { Rat } \\
\text { a- } \\
\text { rat } \\
\text { a }\end{array}$ & $\begin{array}{c}\text { Persent } \\
\text { ase } \\
\text { Ketunta } \\
\text { san }\end{array}$ \\
\hline 39 & $\begin{array}{c}299 \\
2\end{array}$ & 77 & $51,28 \%$. \\
\hline
\end{tabular}

Dilihat dari Tabel 2 di atas menunjukkan bahwa rata-rata nilai siswa sebesar 77 dan ketuntasan belajar klasikal sebesar 51,28\%. Hal ini berarti pembelajaran pada siklus I belum mencapai keberhasilan. Karena menurut Depdiknas (2006), pembelajaran dikatakan tuntas, apabila secara klasikal siswa mendapat nilai rata-rata $\geq 80$ dengan persentase mencapai $75 \%$.

Hasil analisis data nilai aktivitass belajar siswa dalam statistika Siklus 1 di atas terlihat bahwa proses pembelajaran pada siklus I belum dinyatakan berhasil. Ketidak tuntasan atau belum berhasilnya pembelajaran siklus 1 tersebut disebabkan oleh proses pembelajaran statistika dengan penerapan metode hands-on yang belum terlaksana secara optimal, dan masih ada kekurangan selama proses pada aktifitas siswa.

\section{d. Refleksi}

Proses pembelajaran yang telah dilakukan pada siklus 1 menunjukkan bahwa pembelajaran statistika setelah diberi tindakan yang berupa penggunaan metode hands-on pada Siswa kelas IX-E SMPN 1 Cirebon tahun pelajaran 2015/2016 belum dikatakan berhasil. Belum berhasilnya pembelajaran tersebut dikarenakan masih banyak hal yang perlu diperbaiki baik dari segi aktivitas siswa, maupun hasil belajar siswa.

Hasil refleksi analisis observasi siswa pada siklus I terdapat 1 aspek dalam kategori kurang dan 9 aspek dalam kategori sedang. Aspek yang termasuk dalam kategori kurang adalah "siswa mampu menggunakan waktu dengan baik", dengan demikian waktu yang digunakan dalam proses pembelajaran dengan diterapkannya metode hands-on tidak efektif.

Aspek penilaian yang masuk kategori sedang adalah sebagai berikut.

a) Siswa mengikuti pembelajaran materi statistika dengan baik

b) Siswa bersikap disiplin dalam kegiatan belajar mengajar

c) Siswa berusaha memahami materi

d) Siswa mampu bekerja sama dengan siswa lainnya melalui pembelajaran dengan menerapkan metode hands-on

e) Siswa mempresentasikan penyelesaian soal dengan metode Hands-on

f) Siswa mampu memahami pokok bahasan statistika yang sedang diajarkan oleh guru.

g) Siswa mengerjakan soal latihan dan melakukan tugasnya dengan baik

h) Siswa mengemukakan pendapat dan menarik kesimpulan dari materi yang disampaikan.

\section{PELAKSANAAN TINDAKAN SIKLUS II}

Setelah berakhir siklus I, sesuai dengan hasil refleksi, untuk menyempurnakan kekurangan pada siklus maka pada siklus II, akan dilakukan perubahan kegiatan sebagai berikut:

\section{Persiapan (planning)}

Tindakan pada siklus II masih tetap menggunakan metode hands-on dengan materi yang sama yaitu statistika akan tetapi benda yang digunakan adalah sidol atau alat tulis lainnya sebagai alat penunjang metode hands-on. Tahap pertama pada siklus ini adalah tahap perencanaan yang meliputi: 1) Mengidentifikasi kebutuhan siswa, yaitu kebutuhan akan pengetahuan mengenai statistika. 2) Menyeleksi pendahuluan terhadap konsep yang dipelajari, yaitu dengan mempersiapkan dan membuat perencanaan instrument penelitian (RPP, lembar observasi, lembar penilaian). 3) Menyeleksi bahan dan 
masalah yang akan dipelajari, yaitu dengan mempersiapkan alat praktikum dan membuat bahan ajar yaitu materi statistika .

\section{Pelaksanaan (acting)}

Pada pertemuan kali ini bertujuan untuk memperbaiki hasil tindakan pada siklus I yang belum memenuhi kriteria ketuntasan minimal. Kegiatan pendahuluan, guru menyampaikan tujuan pembelajaran, mengingatkan kembali materi pertemuan sebelumnya dan menginformasikan model pembelajaran Hands-on yang akan digunakan.

Dalam kegiatan inti, guru meminta siswa berkelompok. Jumlah anggota kelompok berbeda. Hal ini dimaksudkan agar mendapat data yang bervariasi. Kemudian siswa mengerjakan LKS yang sudah dipersiapkan guru. Selama siswa mengerjakan LKS, guru memberikan bimbingan, bantuan dan mengarahkan siswa yang mendapatkan kesulitan. Kemudian setiap kelompok mempersentasikan di depan kelas, mentukan nilai mean dengan cara mengumpulkan benda (alat tulis) yang diterima, dijumlahkan kemudian dibagi banyak anggota kelompok, siswa yang mendapat benda (alat tulis) lebih dari teman-temannya langsung memberikan pada temannya yang mendapat sedikit dan mengaturnya, sehingga setiap anggota mendapat banyak alat tulis yang sama (nilai/ratarata mean). Kelompok lain dipersilahkan menanggapi, bertanya dan mencatat hasilnya. Guru memadu dan membimbing siswa dalam menentukan jawaban yang benar.

Pada kegiatan penutup, guru membimbing siswa untuk membuat rangkuman materi pelajaran. Kemudian memberikan tugas mengerjakan latihan, siswa diminta menjawab angket yang telah disediakan, untuk mengetahui apakah pembelajaran hari ini menyenangkan atau tidak bagi siswa.

\section{Pengamatan (observing)}

1) Hasil observasi ativitas siswa

Guru observer melakukan pengamtan aktivitas belajar siswa selama KBM sebagaimana siklus sebelumnya. Selanjutnya data yang diperoleh sebagai gambaran aktivitas siswa dalam proses belajar mengajar selama 90 menit, yang disajikan dalam table berikut:

Tabel 3

Persentase rata-rata aktivitas siswa dengan menggunakan metode hands-on pada siklus II

\begin{tabular}{|c|l|c|}
\hline $\begin{array}{c}\text { N } \\
\text { o }\end{array}$ & \multicolumn{1}{|c|}{$\begin{array}{c}\text { Kategori } \\
\text { Pengamatan }\end{array}$} & $\begin{array}{c}\text { Persenta } \\
\text { se } \\
\text { aktivitas } \\
\text { siswa }\end{array}$ \\
\hline 1 & $\begin{array}{l}\text { Siswa mengikuti } \\
\text { pembelajaran } \\
\text { dengan baik. }\end{array}$ & 83 \\
\hline 2 & $\begin{array}{l}\text { Siswa bersikap } \\
\text { disiplin dalam } \\
\text { KBM. }\end{array}$ & 79 \\
\hline 3 & $\begin{array}{l}\text { Siswa berusaha } \\
\text { memahami } \\
\text { materi. }\end{array}$ & 82 \\
\hline 4 & $\begin{array}{l}\text { Siswa mampu } \\
\text { bekerja sama } \\
\text { dengan siswa } \\
\text { lainnya melalui } \\
\text { pembelajaran } \\
\text { dengan } \\
\text { menerapkan } \\
\text { metode Hands } \text { On }\end{array}$ & 76 \\
\hline 5 & $\begin{array}{l}\text { Siswa } \\
\text { mempresentasika } \\
\text { n penyelesaian } \\
\text { soal dengan } \\
\text { metode Hands-on }\end{array}$ & 80 \\
\hline 6 & $\begin{array}{l}\text { Siswa mampu } \\
\text { memahami pokok } \\
\text { bahasan } \\
\text { statistika yang } \\
\text { sedang diajarkan } \\
\text { oleh guru. }\end{array}$ & 82 \\
\hline 7 & $\begin{array}{l}\text { Siswa } \\
\text { mengerjakan soal } \\
\text { latihan dan } \\
\text { melakukan }\end{array}$ & 83 \\
\hline
\end{tabular}




\begin{tabular}{|c|l|c|}
\hline & $\begin{array}{l}\text { tugasnya dengan } \\
\text { baik }\end{array}$ & \\
\hline 8 & $\begin{array}{l}\text { Siswa } \\
\text { mengkomunikasi } \\
\text { kan hasil } \\
\text { presentasi } \\
\text { kelompok lain }\end{array}$ & 82 \\
\hline 9 & $\begin{array}{l}\text { Siswa } \\
\text { mengemukakan } \\
\text { pendapat dan } \\
\text { menarik } \\
\text { kesimpulan dari } \\
\text { materi yang } \\
\text { disampaikan. }\end{array}$ & 79 \\
\hline 10 & $\begin{array}{l}\text { Siswa mampu } \\
\text { menggunakan } \\
\text { waktu dengan } \\
\text { baik. }\end{array}$ & 81 \\
\hline Rata-rata
\end{tabular}

Berdasarkan Tabel 3 menunjukkan bahwa aktivitas siswa yang diamati oleh observer memperoleh nilai sebesar 81 dengan kriteria baik. Hal ini dapat disimpulkan bahwa aktivitas siswa dalam pembelajaran statistika dengan menggunakan metode hands-on pada siklus II telah berhasil.

2) Peningkatan Hasil Belajar Siswa Selanjutnya mengenai data tes peningkatan hasil belajar siswa, disajikan dalam ringkasan table berikut 4.4 .

Tabel 4

Nilai tes hasil belajar siswa siklus II

\begin{tabular}{|c|c|c|c|}
\hline $\begin{array}{c}\text { Juml } \\
\text { ah } \\
\text { siswa }\end{array}$ & $\begin{array}{c}\text { Tot } \\
\text { al } \\
\text { nila } \\
\text { i }\end{array}$ & $\begin{array}{c}\text { Rat } \\
\text { a- } \\
\text { rata }\end{array}$ & $\begin{array}{c}\text { Persenta } \\
\text { se } \\
\text { Ketuntas } \\
\text { an }\end{array}$ \\
\hline 39 & $\begin{array}{c}308 \\
1\end{array}$ & 79 & $92 \%$ \\
\hline
\end{tabular}

Dilihat dari Tabel 4 di atas menunjukkan bahwa rata-rata nilai siswa sebesar 81 dan ketuntasan belajar klasikal sebesar 92\%. Hal ini berarti pembelajaran pada siklus II sudah mencapai keberhasilan. Karena menurut Depdiknas (2006), pembelajaran dikatakan tuntas, apabila secara klasikal siswa mendapat nilai rata-rata $\geq 80$ dengan persentase mencapai $75 \%$.

\section{Refleksi}

Proses dan hasil pembelajaran pada siklus II, dapat dianalisis bahwa aktivitas siswa menunjukan peningkatan. Keberhasilan pembelajaran pada siklus II merupakan akibat dari proses pembelajaran yang sudah optimal yang dilakukan oleh guru.

Dengan digunakannya metode hands-on dalam pembelajaran statistika keberhasilan yang diperoleh; 1) dapat memingkatkan minat siswa untuk melibatkan diri dalam aktivitas pengajaran dan pembelajaran. 2) dapat meningkatkan daya ingatan siswa tentang apa yang dipelajari dengan lebih cepat serta dapat mengingatinya dalam waktu yang lebih lama. 3) aktivitas hands-on juga memudahkan siswa untuk memahami apa yang dipelajari dengan lebih mudah. 4) setelah melalui proses pengajaran dan pembelajaran dengan menggunakan strategi hands on, siswa dapat memindahkan pengalaman yang dipelajari dalam situasi kehidupan yang bersesuaian. 5) Jumlah siswa yang sudah memenuhi kriteria ketuntasan minimal (KKM) meningkat dari 20 siswa menjadi 36 siswa. 4) Rata-rata kelas dalam statistika meningkat dari 77 menjadi 79 .

Dalam meningkatkan hasil belajar siswa tidak hanya diberi latihan terus menerus dengan metode pembelajaran yang sama. Dengan diterapkannya metode hands-on siswa dapat mengidentifikasi masalah, diberi pengalaman secara langsung dan bebas sesuai dengan kemampuannya masing-masing. Siswa mampu mengasah daya analisis dengan pengalaman langsung yang diberikan dalam pembelajaran menggunakan metode hands-on. Dengan keterlibatan siswa secara aktif dapat mengembangkan potensi-potensi, menyadari apa bakatnya, bagaimana kemampuannya dan bagaimana pula keadaan orang lain, sehingga dimiliki 
pengertian tentang dirinya. Ia akan mampu berdiri sendiri dengan segala kelebihan dan kekurangannya, akan merasa mampu memecahkan persoalannya tanpa tergantung pada orang lain. Kesulitan-kesulitan yang dhadapi akan ditanyakan pada orang lain, tetapi pemecahannya adalah atas dasar keputusannya sendiri. Pembelajaran yang dilakukan seluruhnya melibatkan kemampuan siswa, sehingga siswa dapat menyelidiki secara kritis dan dapat menemukan suatu pengetahuan yang dijadikannya sebagai perubahan.

\section{SIMPULAN}

Penerapan metode hands-on dapat meningkatkan hasil belajar siswa kelas IX-E SMPN 1 Cirebon tahun pelajaran 2015/2016 pada materi statsitika. Hal ini ditujukkan pada siklus 1 diperoleh nilai rata-rata kelas sebesar 77 dengan persentase ketuntasan belajar klasikal sebesar $51 \%$ masuk kategori belum berhasil. Pada siklus 2 terjadi peningkatan, untuk nilai rata-rata kelas diperoleh sebesar 79 dengan persentase ketuntasan belajar kalasikal sebesar 92\% dalam kategori berhasil.

Penerapan metode hands-on dapat meningkatkan aktivitas belajar Siswa kelas IX-E SMPN 1 Cirebon tahun pelajaran 2015/2016. Hal ini dapat dilihat dari hasil pengamatan terhadap siswa pada siklus 1 diperoleh skor sebesar 65,7 dalam kategori sedang, kemudian meningkat di siklus 2 sebesar 81 dalam kategori baik.

\section{DAFTAR PUSTAKA}

Arief, A. 2007. Membangun Motivasi Belajar Siswa. http://researchengines.com

Amin, M. 2007. Apa Itu hands-on. http://lubisgrafura.wordpress .com

Arikunto, Suharsimi. 2002. Prosedur penelitian Suatu Pendekatan
Praktek. Jakarta: PT Rineka Cipta

Arikunto, Suharsimi . 2006 . Prosedur penelitian Suatu Pendekatan Praktek. Jakarta: PT Rineka Cipta

Bob Script. 2004. Fasilitas Peragaman Ilmu Pengetahuan Dasar di Malang.

http://www.geocities.com

Dimyati dan Mudjiono. 2006. Belajar dan Pembelajaran. Jakarta: Rineka Cipta

Depdiknas. 2008. Sistem Penilaian KTSP. $\quad$ http://bpgdisdikjabar.com

Hamalik, Oemar. 2001. Proses Belajar Mengajar. Jakarta: PT Bumi Aksara

Juri, Mohamad. 2008. Penerapan ELearning Dalam Pembelajaran Suatu Langkah Inovasi. http://researchengines.com

Mulyasa, E. 2007. Kurikulum Tingkat \begin{tabular}{llr} 
Satuan & \multicolumn{2}{r}{ Pendidikan. } \\
Bandung: & PT & Remaja \\
Rosdakarya & &
\end{tabular}

Muslikah. Pemberdayaan Sekolah Dalam Menerapkan Model Pembelajaran Berbasis Komputer.

http://media.diknas.go.id

Nasution, S. 2004. Didaktik Asas-Asas Mengajar. Bandung: PT Bumi Aksara

Nanath. 2008. Faktor personal yang mempengaruhi tingkah laku manusia.

http://kuliahkomunikasi.com

Onitsuka. 2011. Pembelajaran Secara Hands-on. Pyzam.com. 
Pujadi, Arko. 2007. Faktor-Faktor Yang mempengaruhi Motivasi Belajar. http://www.ubm.ac.id

Robinson, D.N. Adjai. 1988. Asas - Asas Praktik Mengajar. Jakarta: Penerbit Bhratara

Rahadi, Aristo. 2008. Pembelajaran Dalam Pendidikan Jarak Jauh.

http://aristorahadi.wordpress .com

Ryanti. 2009. Pembelajaran Biologi

Dengan Group Investigation Melalui Hands On Activities dan Elearning Ditinjau http://digilib.uns.ac.id

Ruseffendi. 2005. Dasar - Dasar Penelitian Pendidikan dan Bidang Non-Essakta Lainnya. Bandung: Tarsito

Slameto. 2003. Belajar Dan Faktor Faktor Yang Mempengaruhinya. Jakarta: Rineka Cipta

Triluqman, Heri. 2007. Belajar dan Motivasi.

http://heritl.blogspot.com 